\title{
THE NEW DELIVERY MODEL OF THE COMMON AGRICULTURAL POLICY AFTER 2020 - CHALLENGES FOR POLAND
}

\author{
ADAM WAS \\ AGATA MALAK-RAWLIKOWSKA \\ EDWARD MAJEWSKI
}

\begin{abstract}
The Common Agricultural Policy (CAP) of the European Union is the subject of the consecutive reform. The proposal of the CAP after 2020 has been presented in the European Commission's proposal on 1 June 2018, which defines the proposed forms and scope of the EU agriculture support after 2020. The innovative solutions suggested by the European Commission impose many new obligations on Member States. However, they are associated with significant challenges resulting both from the need to define national strategies as well as obligations to implement policy instruments and measure policy implementation effects.

The main objective of this study is to discuss the key implications for Poland resulting from the new delivery model of CAP after 2020 proposed by the EU Commission and to identify the most important "challenges" for policy makers and the entire agricultural sector.

In the new perspective of the $C A P$, no radical changes in the very essence of the Common Agricultural Policy of the EU are foreseen. The basic objectives of the CAP still include supporting agricultural incomes, improving the competitiveness of the EU agriculture or supporting rural development. The main distinguishing feature of the new CAP model, as compared to the existing one, is the fact that individual Member States have a large degree of freedom in
\end{abstract}

Dr hab. Adam Wąs, Szkoła Główna Gospodarstwa Wiejskiego, Wydział Nauk Ekonomicznych, Katedra Ekonomiki i Organizacji Przedsiębiorstw; ul. Nowoursynowska 166, 02-787 Warszawa (adam_was@sggw.pl. ORCID iD:0000-0001-8643-5985.

Dr inż. Agata Malak-Rawlikowska, Szkoła Główna Gospodarstwa Wiejskiego, Wydział Nauk Ekonomicznych, Katedra Ekonomiki i Organizacji Przedsiębiorstw; ul. Nowoursynowska 166, 02-787 Warszawa (agata_malak_rawlikowska@sggw.pl).ORCID iD: 0000-0002-1484-0989.

Prof. dr hab. Edward Majewski, Szkoła Główna Gospodarstwa Wiejskiego, Wydział Nauk Ekonomicznych, Katedra Ekonomiki i Organizacji Przedsiębiorstw; ul. Nowoursynowska 166, bud. 7, pok. 106, 02-787 Warszawa (edward_majewski@sggw.pl). ORCID iD: 0000-0003-0886-6645. 
shaping national policy in relation to agriculture and rural areas, but they have the obligation to determine measurable effects and selection of instruments, while maintaining the Community nature of the CAP.

For Poland, as well as for all Member States, the key challenge is the objective identification of needs of the agriculture and rural areas, and then to select indicators and instruments to effectively achieve the objectives of the CAP. One of the main challenges for Poland is also to include in the strategic plans objectives related to environmental and climate policy, and improvement of the position of farmers in the food supply chain. Another issue that raises the discussion is the policy of supporting agriculture in the form of direct payments and the issue of inequalities in their distribution.

Keywords: Common Agricultural Policy, agriculture, agriculture support, EU agricultural policy, CAP reforms.

JEL codes: Q18, Q15, Q01, Q14.

\section{Introduction}

The European Union's Common Agricultural Policy (CAP) is the subject of another debate on its shape after 2020, which is a part of the process of successive evolution and periodic, radical transformations of the CAP since its establishment in 1957. The outcome of the current debate on the shape of the new CAP is the proposal by the European Commission presented on 1 June 2018 (COM, 2018a), which defines the forms and scope of the EU agriculture support after 2020.

In general, the Common Agricultural Policy proposed after 2020 is largely a continuation of the EU agricultural policy from the previous programming period. This statement specifically refers to the fact that the invariable primary CAP objective is to support agricultural income and to cover the agricultural sector and rural areas with agricultural policy. Just like before, at least in a declarative sense, the CAP is to build on the three basic principles laid down in the 1957 Treaty of Rome: single market (equal treatment of producers in all Member States of the Community), preference (according to which, products originating in the Member States of the Community take precedence over imported products), and solidarity (primarily within the meaning of the solidary share of each Member State in financing the Common Agricultural Policy).

In the studies of the European Commission on the EU agricultural policy, there are clear references to the provisions of the Treaty of Rome and what is stressed with regard to the foundation of the EU food economy is a need to maintain the well-functioning "internal market" for agricultural products and food (COM, 2017).

As the CAP is being reformed, and, at the same time, in view of the growing internal tension among the Member States, due to the divergence of interest, different views on the agricultural policy and external pressures, there may be some doubt as to the extent to which these principles will continue to apply (Majewski and Malak-Rawlikowska, 2018). 
It, therefore, seems that, as to the essence and the basic instruments, the Common Agricultural Policy after 2020 will not be radically modified, however, the modifications presented in the proposal of the European Commission go beyond the normal adjustments made over time and in view of economic changes in the functioning of the agricultural sector.

The proposal for a Regulation of the European Parliament and of the Council (COM, 2018) included two kinds of innovative solutions:

- Taking into account new challenges towards agriculture and the agricultural policy, inter alia, in relation to climate change as well as taking into account the existing diversity of environmental and socio-economic conditions in the Member States. This is particularly important, since the universal nature of the existing CAP could not be equally adjusted to tackling specific problems of agriculture and rural areas in individual EU countries. The decreasing effectiveness of universal instruments resulted from: the enlargement of the European Union with countries whose environmental and socio-economic conditions were completely different from those in the original fifteen countries and from diversified needs and expectations towards the CAP in the individual regions of the Union.

- Major change in the relations between the European Commission and Member States in the process of creating detailed agricultural policy solutions as well as enforcing implementation of objectives, reporting and financing of the CAP.

The innovative solutions suggested by the European Commission impose a number of new obligations on the Member States. These entail important challenges arising from both a need to define national strategies and a need to introduce, implement and control technical solutions.

The main objective of this study is to consider the key implications for Poland resulting from the new model of the CAP functioning after 2020 and to identify key - according to the authors - challenges for policy makers and the agricultural sector as a whole. As indicated in the title, the article is partly a discussion and its key objective is to inspire a nation-wide debate.

\section{Evolution of the CAP objectives}

Along with the evolution of the EU Common Agricultural Policy throughout its existence, also its major objectives have been modified during subsequent reforms. This resulted mainly from changes taking place in the macroeconomic environment of the agricultural sector in relation to all fundamental factors of this environment - social, technological, economic and political. The relations between changes in the economic environment and the modification of the CAP objectives and instruments deserve a separate analysis. This goes beyond the framework of this article, and thus we will only briefly elaborate on the thought expressed above. 


\section{Economic factors}

The systematic strong increase in the productivity of production factors was one of the reasons why the agricultural policy stopped to stimulate growth of agricultural production as it was during the initial period, and in certain periods of the excessive food supply, the production was even reduced. The most significant aspects of the agricultural policy also include maintaining the decent level of agricultural income and striving for reducing its diversification, which is invariably the primary CAP objective. Most recently, the formulation of the CAP objectives is more and more determined by the factors related to risk in the agricultural production.

\section{Technological factors}

Technical progress contributed to the successive increase in the agricultural productivity, but also generated effects such as a drastic reduction in demand for agricultural labour and adverse environmental impacts. This was important for formulating the CAP objectives in the social and environmental areas.

\section{Political factors}

The CAP objectives and shape were continually determined by the political conditions within the European Union, such as a need for consensus on key issues in relation to the diversified interests of the Member States as well as external pressures. First of all, it is important to stress here the importance of the political impacts related to the GATT negotiations, followed by the WTO negotiations, or the bilateral relationships, inter alia, between the European Union and the United States.

\section{Social factors}

The social component of the macroeconomic environment has evolved significantly over time, exercising an ever-growing impact on the shape of the CAP. This applies to both the social and economic status of the agricultural population in the context of changes in agriculture itself and in rural areas, as well as the changing expectations of food consumers and taxpayers.

Therefore, the process of formulating the objectives of the Common Agricultural Policy was affected by different forces, and their resultant determined the form of modification of the CAP objectives and instruments.

Table 1 outlines the objectives of the EU agricultural policy applicable in three key periods - at the beginning of the CAP (Treaty of Rome), Agenda 2000, which is a "development and extension" of the fundamental reform of the CAP covered by the McSharry package of 1992 (Agenda 2000, 1997) and those currently proposed by the European Commission for the reformed CAP after 2020. 
Table 1

Comparison of the objectives of the EU Common Agricultural Policy in the selected periods

\begin{tabular}{|c|c|c|}
\hline Trea & Agenda 2000 & Proposal of the Commission for 2020 \\
\hline $\begin{array}{l}\text { - Improved pro- } \\
\text { ductivity of } \\
\text { agriculture } \\
\text { through suppor- } \\
\text { ting technical } \\
\text { progress, ratio- } \\
\text { nal development } \\
\text { of the agricultu- } \\
\text { ral production } \\
\text { as well as the } \\
\text { optimal use of } \\
\text { production fac- } \\
\text { tors, especially } \\
\text { labour; } \\
\text { - Ensuring ade- } \\
\text { quate standard } \\
\text { of life of the } \\
\text { rural popula- } \\
\text { tion, especially } \\
\text { through } \\
\text { raising individu- } \\
\text { al earnings } \\
\text { of persons } \\
\text { employed } \\
\text { in agriculture; } \\
\text { - Market } \\
\text { stabilisation; } \\
\text { Ensuring } \\
\text { food supplies; } \\
\text { Ensuring } \\
\text { reasonable } \\
\text { prices for } \\
\text { consumers. }\end{array}$ & $\begin{array}{l}\text { - Improving the } \\
\text { competitiveness of } \\
\text { agriculture of the European } \\
\text { Union on both internal and } \\
\text { external markets; } \\
\text { - Ensuring food safety and } \\
\text { quality to consumers within } \\
\text { and outside } \\
\text { of the European Union; } \\
\text { - Ensuring a fair standard of li- } \\
\text { ving to farmers and } \\
\text { stabilisation } \\
\text { of agricultural income; } \\
\text { - Integrating the environmental } \\
\text { objectives into the EU } \\
\text { Common Agricultural Policy } \\
\text { and greater involvement } \\
\text { of farmers in management } \\
\text { of natural resources; } \\
\text { - Creating additional sources } \\
\text { of income on the farm and } \\
\text { the possibilities of achieving } \\
\text { alternative } \\
\text { income and employment } \\
\text { outside agriculture for } \\
\text { farmers and their families; } \\
\text { - Contribution of the } \\
\text { agricultural and rural } \\
\text { policy to strengthening } \\
\text { economic cohesion within } \\
\text { the European Union. }\end{array}$ & $\begin{array}{l}\text { - Supporting income to ensure the viability } \\
\text { and resilience of farms throughout the Union } \\
\text { so as to increase food security; } \\
\text { - Strengthening market orientation and } \\
\text { improving competitiveness, taking account } \\
\text { of a greater emphasis on research, technology } \\
\text { and digitisation; } \\
\text { - Empowering farmers in the value chain; } \\
\text { - Contributing to climate change mitigation } \\
\text { and adaptation as well as to the use of susta- } \\
\text { inable energy; } \\
\text { - Acting for the sustainable development and } \\
\text { efficient management of natural resources } \\
\text { such as water, soil and air; } \\
\text { - Contributing to the protection of biodiversity, } \\
\text { provision of ecosystem services and protec- } \\
\text { tion of habitats and landscapes; } \\
\text { - Attracting young farmers and facilitating } \\
\text { the development of economic activities } \\
\text { on rural areas; } \\
\text { - Promoting employment, growth, social } \\
\text { inclusion and local development on rural } \\
\text { areas, including the bioeconomy } \\
\text { and sustainable forestry; } \\
\text { - Improving the EU agriculture's response to } \\
\text { social needs regarding food and health, } \\
\text { including safe, nutrient-rich and sustainably } \\
\text { produced food, preventing food waste, } \\
\text { as well ensuring animal welfare. }\end{array}$ \\
\hline
\end{tabular}

Source: own study using: Article 33(1) of the Treaty of Amsterdam (formerly Article 39 of the Treaty of Rome), Agenda 2000 (1997), COM (2017).

From the analysis of the above Table it results that throughout its existence, the essential objectives of the Common Agricultural Policy of the EU should include shaping the proper level of income and standards of living of the agricultural (rural) population and ensuring food supply. For these two categories of objectives, only the wording, scope and means of achieving them have changed. The next wordings of the CAP talk about "stabilisation of income" (Agenda 2000, 1997) and the "viability and resilience of farms" to shocks. Moreover, the importance of income from the non-agricultural activity is stressed (COM, 2017).

Similarly, the objective kept over the entire term of the CAP is to meet the food needs of the EU Member States, however, the way of articulating these needs 
is clearly evolving. While the Treaty of Rome mentions ensuring food supply to consumers at reasonable prices (which is obvious in terms of post-war food shortages and the impoverishment of the European society), the objective of the Agenda 2000 refers to the food quality, including safety for consumer health, resulting from growing societal expectations.

The significant evolution has been made with regard to the basic task of agriculture, i.e. the production of agricultural raw materials and food. Along with a growth in productivity of factors of production in the European agriculture, which resulted in surpluses of agricultural products, the EU agriculture had to face the challenge of managing the food surpluses and reducing a negative environmental impact of the intensified agricultural production. The CAP objectives from that period included the strive for improving the competitiveness of the EU agriculture and environmental protection requirements.

The proposal of the European Commission of 2018 (COM, 2018a) brings about new objectives (empowering farmers in the supply chain) or those which are differently formulated, for example, in terms of strengthening the competitiveness of European agriculture. What is also characteristic is the significant strengthening and development of environmental objectives, with a marked impact on climate change. The need to involve agriculture in efforts for the environment and the production of public goods has been strongly accentuated even in the objectives of the Agenda 2000. The set of implemented CAP instruments for the implementation of these objectives (e.g. cross compliance) has been then extended by greening in the CAP for the last budgetary perspective 2014-2020. An example of introducing the environmental objectives into the CAP is characteristic and indicates a certain pattern in the process of modifying the Common Agricultural Policy - consideration of the economic and political context, emerging challenges and growing social expectations. In the case of the environmental objectives, the risks arising from the unrestricted intensification of the agricultural production have become the cornerstone of implementing the environmental protection requirements both in the McSharry reform and in the Agenda 2000. Dissatisfaction with the results achieved and "aspirations to shape more environmentally friendly agriculture" (Agenda 2000, 1997) led to further modifications of the CAP. Again, the lack of expected environmental benefits due to greening ${ }^{1}$ (Agenda 2000, 1997; Pe'er et al., 2017; Hart et al., 2017) and emerging challenges (climate change, growing societal expectations) resulted in greater significance of the environmental objectives in the CAP proposal after 2020.

\footnotetext{
${ }^{1}$ One of the problems of "greening" was that the unified instruments relating to the achievement of environmental objectives could not be effectively implemented in the diversified environmental conditions and socio-economic realities of the Member States. This was a compromise resulting from these differences, and also from the way of creating the EU legislation which required consensus to be reached. As a result, the Commission's initial greening proposal has been significantly "weakened" in this process (Agenda 2000, 1997).
} 
The similar evolution took place in the case of the CAP objectives regarding social aspects - from orientation towards meeting basic food needs to safe food and meeting the requirements of Sustainable Development on rural areas. As stated by Król (2013, p. 402), "The original objectives of the Common Agricultural Policy (CAP) have remained unchanged since the 1950s. However, with regard to the rural development policy and its legal principles, we can notice its integration with the concept of sustainable development".

A clear context emerges from the new objectives of the Common Agricultural Policy - a response to the challenges of the ever-changing macroeconomic environment and climate, but above all the action compliant with the Sustainable Development paradigm. We reckon that the below fragment from the proposal of the European Commission should be quoted at this point:

"Unlike most other economic sectors, farming is strongly affected by the weather; it is also frequently tested by volatile prices, natural disasters, pests and diseases - with the result that, every year, at least $20 \%$ of farmers lose more than $30 \%$ of their income compared with the average of the last three years. At the same time pressure on natural resources is still clearly present partly as a result of some farming activities. Climate change threatens to make all of the above-mentioned problems weigh more heavily. The Common Agricultural Policy (CAP) should therefore lead a transition towards a more sustainable agriculture.

The CAP enabled the development of the most integrated single market. It is thanks to the CAP that the EU farm sector is able to respond to citizens' demands regarding food security, safety, quality and sustainability. However, at the same time the sector faces the challenges of low profitability - due inter alia to the EU's high production standards, the high costs of production factors and the fragmented structure of the primary sector" (COM, 2017, p. 4).

This quote contains three general objectives of the future CAP, divided in the previously presented (Table 1) specific objectives:

- Support for the smart, resilient and diversified agricultural sector ensuring food security;

- Increasing the care for the environment and climate action in order to contribute to achieving the EU environmental and climate goals;

- Strengthening the socio-economic structure of rural areas (COM, 2017).

\section{New model of the EU Common Agricultural Policy after 2020 (New Delivery Model)}

With the modification of the CAP objectives, the European Commission proposed a new scheme for implementing the agricultural policy, defined as a "New Delivery Model" (Hogan, 2018).

The essence of this model is that each EU Member State is shaping an individualised agricultural policy that takes into account the specificities of the ag- 
riculture sector and economic and environmental conditions of its functioning in the given country while maintaining the principal CAP rules and responsibility for implementing the EU objectives of the agricultural policy. This means that what is still applicable are the rules of the Treaty of Rome and the general CAP objectives formulated at the EU level, there is also the "central" CAP budget. However, the Member States will have more freedom in establishing national objectives and selecting agricultural policy instruments to implement these objectives. These objectives and tools are to be presented and approved by the European Commission. The Member States, however, bear full responsibility for achieving the established outcomes and this determines the scale of financing of the actions implemented from the central CAP budget.

A key novelty in the CAP model, according to the proposal of the Commission, is that the essence of the CAP implementation is the achievement of the assumed agricultural policy objectives and not the compliance with accepted restrictions (e.g. cross compliance). With that, the scope of responsibility of the European Commission and the Member States for the individual stages of programming and implementation of individual, national policies is changing, as shown in Figure 1.

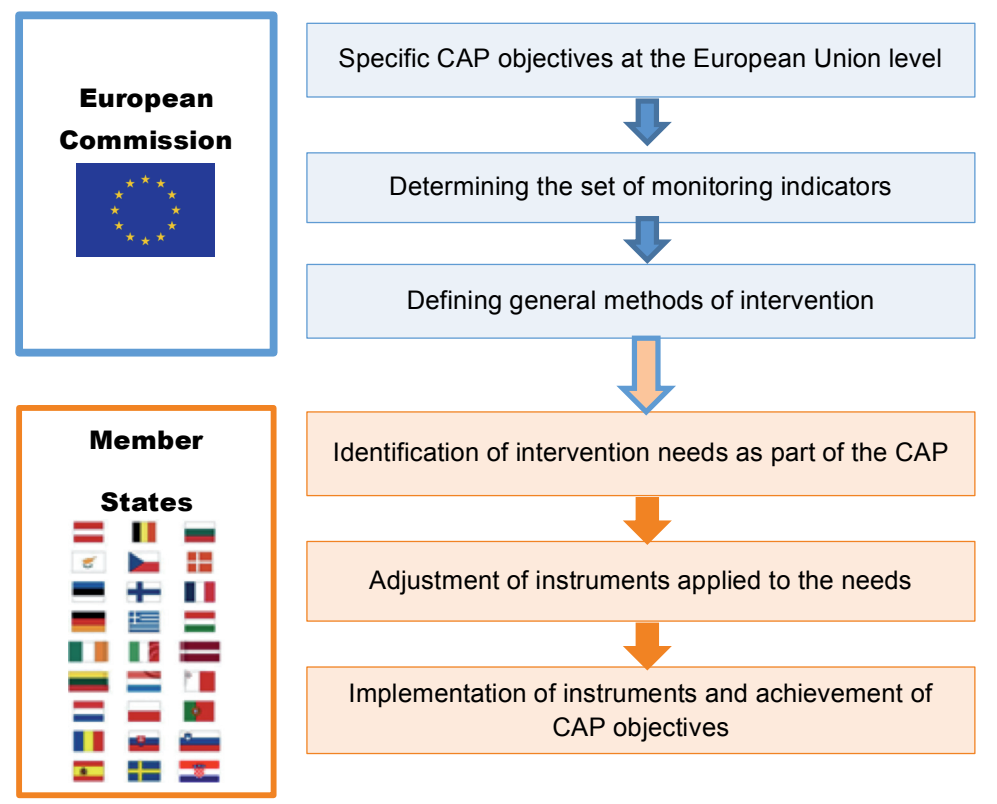

Fig. 1. General scheme of creating and implementing the CAP after 2020 according to the proposal of the European Commission.

Source: own study based on Haniotis (2018).

The initial assumption inspiring this institutional change is the preservation of the European added value and the provision of conditions for the functioning of the internal market for agricultural products, by deciding on the methods of inter- 
vention by the Member States, but not in isolation, as it has been so far, but within a structured process, the final result of which is the Community action programme consisting of 27 national CAP strategic plans.

In the new model, the European Commission should formulate general and specific CAP objectives applicable across the European Union, establish a set of indicators to measure the degree of achieving these objectives and a set of agricultural policy instruments to be applied in the Member States.

On the other hand, the Member States create their own strategic plans, the implementation of which must be associated with the implementation of the specific CAP objectives (Table 1). The development of these plans determines the receipt of the European Union financial support, both from the European Agricultural Guarantee Fund (first pillar) and the European Agricultural Fund for Rural Development (second pillar).

An illustration of the scheme of creating and implementing the CAP after 2020 is an example of programming the actions and achieving the objectives in the new CAP model (Fig. 2), which applies to the specific objective of supporting economic viability of farms and improving their "resilience".

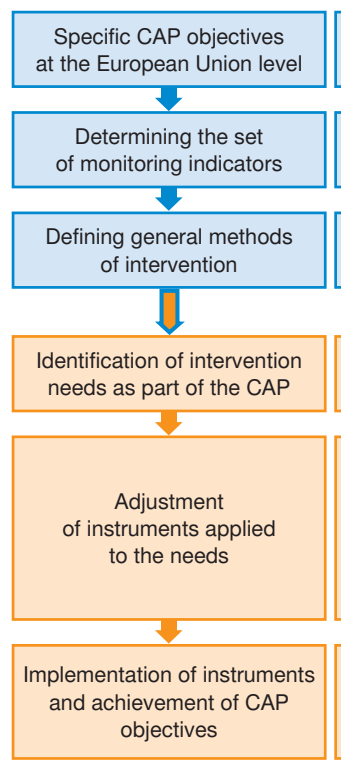

Support for income to provide the viability and resilience of farms in the EU

Reduction in the variability of agricultural income

Indicator: variability of income (share of farms with the decrease in income by more than $30 \%$ a year)

Article 39 of the Treaty of Rome (CAP objective)

Ex ante assessment to determine the needs to reduce the variability of income

Demonstrating how the plan will contribute to reducing the variability of income

Determining expected results: share of UAA to which support for income was granted

and the basis of conditionality, percentage of farmers using risk management instruments,

percentage of farmers receiving subsidies to production, etc.

Selection and definition of intervention instruments: decoupled support, subsidies

to production, income stabilisation instruments, etc.

Assessment of effects based on the impact indicators

Monitoring progress in achieving established objectives according to the result indicators

Fig. 2. Example of the process of creating and implementing instruments under the strategic plans. Objective - stabilisation of agricultural income as part of the new CAP after 2020

Source: own study based on the materials of the European Commission (COM, 2018b).

The strategic plan is a document drawn up by each Member State which shows a strategy of intervention in agriculture and rural areas in the country concerned. Its essence is to adopt measurable objectives, the implementation of which is assessed on the basis of the output, result and impact indicators selected from the Commu- 
nity set of indicators (examples of indicators are shown in Annex 1). The output indicators refer to the results of individual interventions called outputs in the regulation. As exemplary output indicators, we can mention: number of beneficiaries or UAA covered by support under each instrument. The result indicators refer to the specific objectives contained in the strategic plan and are used to monitor the implementation of the milestones and final effects of the implementation of the plan. These may include indicators such as the share of farms using risk management tools or the share of UAA covered by income support and subject to conditionality. The impact indicators are applied in the context of the general and specific objectives of the entire CAP (COM, 2018a, Articles 5 and 6), for example, changes in the income parity of farmers, the level of greenhouse gas emissions from agriculture, organic matter content in soil. Due to the indicators introduced, methods of monitoring and dependence of funds payments on achieving individual objectives, the new CAP model is defined as "performance-based".

Pursuant to the objectives adopted, the Member States may choose the types and tools of intervention set out in the Regulation of the Commission and of the European Parliament (COM, 2018a), which, in principle, correspond to the existing solutions under the first and second pillar of the CAP, i.e.:

- Direct payments, including: decoupled ${ }^{2}$ and coupled (e.g. subsidies for legumes, protein crops, hops or dairy cows and cattle for meat), pursuant to Article 14 (COM, 2018a);

- Payments related to rural development ${ }^{3}$, pursuant to Article 64 (COM, 2018a).

The identification of the given Member State's needs should result from the studies and analyses, which are an obligatory part (basis) of each plan (COM, 2018a, Article 95).

The CAP strategic plan is to be drawn up for the period from 1 January 2021 to 31 December 2027 for each Member State "with respect to its entire territory" (COM, 2018a, Article 93). It is possible to differentiate elements of the strategic plan at the regional level, but they must be integrated into the strategic plan of the country, which is then presented to and agreed with the European Commission. Strategic plans will be subject to negotiations with the European Commission, just like the regional and national rural development programmes were negotiated and approved in the past. In the new CAP model, the European Commission will approve the 27 national strategic plans and not dozens of different documents, as it used to be in the past. For example, in the budgetary perspective for 2007-2013 the European Commission notified 26 direct support schemes and agreed 118 rural development plans and 65 sectoral strategies with the Member States.

The task of drawing up and implementing strategic plans is, therefore, the responsibility of the Member States and the European Commission assumes a role

\footnotetext{
${ }^{2}$ Basic income support for stability purposes, complementary redistributive income support for stability purposes, complementary income support for young farmers, climate and environment schemes.

${ }^{3}$ For example, agri-environment-climate programmes, subsidies for natural and specific constraints (formerly LFA), investments, risk management tools.
} 
of a protector of the CAP principles such as the Community nature of the policy, creation of European added value, respect for the principles of equal treatment of all EU farmers, or the achievement of the EU climate and energy objectives.

The Member States are given considerable freedom in shaping an individualised strategic plan which takes into account the specific circumstances and needs. A significant facility in creating support tailored to the needs is the introduction of a possibility of transferring the budget funds between the first and the second pillar in the range of $+/-15 \%$ of the financial resources (COM, 2018a, Article 90). This transfer can take place in any direction. In addition, the transfer of funds from the first to the second pillar may be increased by 15 percentage points (pp), provided they are used for environmental and climate interventions and by 2 pp provided they are intended to support setting up of young farmers.

The European Commission defines a set of conditions for providing support from the CAP budget, which must be absolutely respected. They are presented in detail in the proposal for the Regulation. Below, we present the exemplary, most important restrictions.

- By assumption, at least $30 \%$ of the funds in each strategic plan should be allocated for interventions aiming at achieving the environmental and climate objectives (COM 2018a for the EAGF and for the EAFRD). Taking into account pressures on the part of non-governmental organisations (EEB, 2018), it is expected that the implementation in individual countries will be higher than the set limit, which will allow to achieve the expenses for these objectives at the level of $40 \%$ of the budget (COM, 2018c).

- Another restriction imposed on the Member States is an obligation to reduce direct payments paid to the largest beneficiaries. According to the proposal of the European Commission, a reduction would cover the amount of direct payments if, after deducting the costs of paid labour and estimated costs of unpaid labour, this amount exceeded EUR 60 thousand per farm. A differentiated reduction scale of payments is proposed: from a $25 \%$ reduction in the case of amounts not exceeding EUR 75,000, up to even 100\% after exceeding the amount of EUR 100,000 (COM, 2018a, Article 15). The funds obtained from the reduction of payments may be transferred to measures financed under the second pillar, excluding the above limits.

- The previously applicable requirements regarding direct payments to promote the implementation of the environmental objectives were extended with the introduction of "conditionality" in direct payments (Fig. 3). 


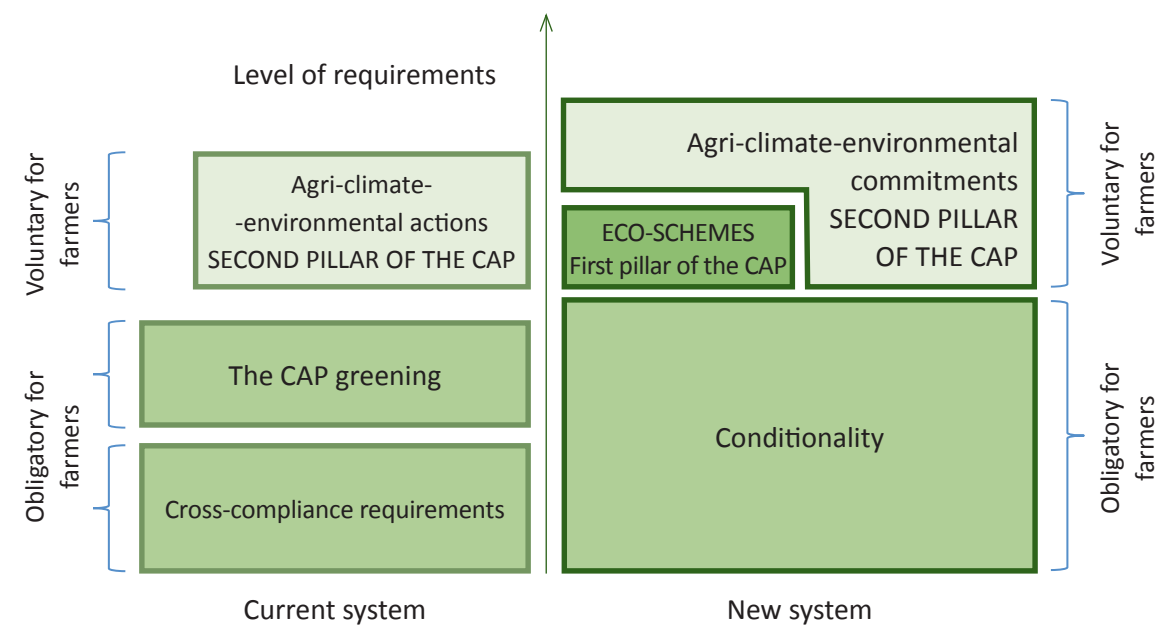

Fig. 3. Changes in the system of support for measures for the environment and climate under the current and new (after 2020) CAP system.

Source: own study based on Haniotis (2018).

Unlike the current legislation, according to which a failure to comply with some requirements could result in a loss of about $30 \%$ of the direct payments per single farm (payment for greening), the new solution makes receiving support conditional upon the compliance with the "basic environmental, climate change, public health, animal health, plant health and animal welfare standards" (COM, 2018a, p. 22). In the case of non-compliance with the standards, sanctions are envisaged, ranging from a few percent to even the whole amount of due direct payments.

In addition to the conditionality, the European Commission has proposed incentives for environmental and climate actions going beyond the basic standards that will be financed from the first pillar of the CAP. They are included in the new CAP instrument called "Eco-schemes" (COM, 2018a, Article 28). The scope of interventions in this instrument is similar to that of agri-environmental programmes used for years. A novelty is financing of these activities from the $1^{\text {st }}$ Pillar of the CAP and the related regime for the settlement of environmental payments in annual campaigns. The new mechanism creates more opportunities for Member States. Namely, while maintaining the existing support mechanism for pro-environmental measures (agro-environmental-climate programmes), it creates the possibility of a dual approach in which simpler measures, to a lesser extent going beyond the generally applicable environmental regulations, could be financed from the first pillar (at the expense of reducing the envelope of direct payments), while more ambitious measures, financed from RDP resources, would be implemented under the second pillar. 


\section{Challenges of the new CAP}

By entering into a discussion on the shape of the future CAP after 2020, we must outline the context, in the sense of key conditions that determine both the objectives of the reformed CAP and the applicable instruments which, at the level of the strategic plan, will be defined in each Member State. This context consists mainly of:

\section{1) Conclusions from the analysis of efficiency of the existing agriculture support system under the CAP and assessment of the needs of agriculture and rural areas in the $E U$}

It seems that the existing agricultural policy has been fairly efficient in achieving the basic CAP objectives, particularly with regard to support for and stabilisation of agricultural income. One of the more important, priority changes in the existing CAP applies to the greater involvement of the Member States' agricultural sector in achieving the environmental and climate objectives, which results, inter alia, from critical assessments of greening effects. Therefore, financing for actions serving the achievement of these objectives from the two pillars of the CAP will be maintained.

As proposed by the Regulation, the obligatory share of the funds allocated for voluntary and obligatory environmental and climate actions (e.g. eco-schemes, balancing of biogenic elements (N, P) on farms, agri-climate and environmental programmes) should amount to at least $30 \%$ of the budget allocated for implementing the strategic plan both from the first and the second pillar of the CAP.

Ultimately, the first pillar includes, as it did so far, direct support for agriculture, with the main objective of annual payments to farmers "to help stabilise farm revenues" and complementary coupled payments, which are to tackle specific market situations and to support trade promotion (COM, 2017).

The second pillar of the CAP provides funds to support rural development, enabling the financing of various actions to enhance the competitiveness, improve the natural environment or achieve social objectives. On the other hand, an important novelty in the proposed system is that it enables a possibility of transferring funds between the pillars, which will be decided by the Member States in their strategic plans.

The growing doubts about the uneven distribution of direct payments made the European Commission introduce further restrictions in relation to the existing support systems of agricultural income. In view of the increasing concentration of the land, payments are distributed among farmers almost according to the Pareto principle. Support for the group of the largest farms may be justified by their significant share in implementing the basic function of agriculture, i.e. satisfaction of food needs. However, the new agricultural policy is increasingly stressing the social and environmental problems, which can justify more evenly distributed support for all farmers. However, at least in Poland, it becomes, in a substantial part, a method of social assistance for a certain group of the rural population. 


\section{2) External pressures on the part of the market and macroeconomic environment}

Particularly in the European Union countries, there is a growing pressure to reduce the harmful environmental impact of the economy, including agriculture. For decades, the EU agricultural policy has been imposing further requirements to reduce the negative environmental impact aimed at, inter alia, reducing the run-off of biogenic elements into groundwater and surface waters, reducing erosion or preserving biodiversity. Agriculture is a major emitter of greenhouse gases (GHGs). GHGs emissions from agriculture are estimated at 15\% on the global scale, $10.3 \%$ on the EU scale and 7.5\% in Poland (KOBiZE, 2018; Sulewski, Majewski and Wąs, 2018). So far, the agricultural sector has not been subject to restrictions in this context, but it can be expected that, following the provisions of the climate policy, also agriculture will be required to reduce greenhouse gas emissions. What should be noted at this place, is a certain paradox associated with the relations between excessive greenhouse gas emissions and agricultural activity. GHGs emissions are said to have impact on climate change, which particularly strongly and adversely affects the conditions of agricultural production. This increases the production and income risks in agriculture, due to which financial support of agriculture must be continued and this, due to the intensification of agricultural production, can generate increased greenhouse gas emissions.

Another kind of pressure on agriculture comes from the markets of agricultural products and food and results from the growing competition. The increasing variability of prices in food markets and the appearing trends of "nationalisation" of food production pose a threat to maintaining stable income for farmers which guarantee the continuous functioning of farms and thus ensuring food security.

At the same time, there are changes in the demand structure related to the growing wealth of the population and the increasing requirements of more and more aware consumers regarding the quality of food delivered, its origin and methods of its production. In combination with the more restrictive requirements applicable in the European Union in relation to the natural environment, this may mean a need to incur additional inputs and the increase in the costs debilitating the competitiveness of the EU agriculture on the global markets. This requires the necessary adjustments to the agriculture sector and food processing to expected support for actions aimed at materialising the idea of smart agriculture and improving food quality.

The availability of labour resources is an important factor in the macroeconomic environment. In recent years, the long-term overpopulation in the Polish countryside, which manifested itself in a phenomenon of the so-called "hidden unemployment" has been losing its significance. The dynamic development of other branches of the economy and the growing mobility of the rural population contributed to improving the efficiency of allocation of labour inputs and thus to limiting their availability in agriculture. This results both in rapid investment processes, evident particularly in large farms and aimed at reducing the labour-intensity of production, 
and in the significant increase in employing foreigners in the agricultural sector, mainly on horticultural farms, where the most labour-intensive fruit and vegetable harvesting processes cannot be mechanised. In these sectors, the lack of sufficient labour resources is already becoming a problem.

\section{3) Polish negotiating position}

In negotiations with the European Commission, Poland presents a position which can generally be presented as expectations regarding (Projekt stanowiska RP, 2018):

- Faster alignment of direct payment rates between the EU Member States providing a level playing field to compete,

- Stronger support for economic and social cohesion in rural areas,

- Strengthening support for climate action;

- Empowering farmers in the supply chain and reducing the variability of agricultural income.

While the last three expectations are not in contradiction with the assumptions of the new CAP proposal, controversy is caused by the postulate to align direct payment rates which has been voiced from many years. Direct payments are, undoubtedly, aimed at stabilising income and improving the quality of life, while their impact on improving the competitiveness is questionable, also for this reason that it "exempts" many producers from acting towards increasing the efficiency of management.

Publicising the postulate to align direct payment rates in Poland seems understandable due to the expectations of farmers and the necessity to demonstrate that the Government is fighting for better conditions for the Polish farmers. However, it can be assumed that the programmed process of gradual aligning of payment rates will not be accelerated due to resistance in those countries where these rates are reduced.

\section{Challenges for Poland}

One major challenge for the Common Agricultural Policy is an attempt to deliver a comprehensive set of diversified objectives, expressed by the European Commission, in the following statement:

"Europe needs a smart, resilient, sustainable and competitive agricultural sector in order to ensure the production of safe, high-quality, affordable, nutritious and diverse food for its citizens and a strong socio-economic fabric in rural areas. A modernised Common Agricultural Policy must enhance its European added value by reflecting a higher level of environmental and climate ambition and addressing citizens' expectations for their health, the environment and the climate" (COM, 2018a, p. 1).

The so-defined effects of the new CAP should not cause controversy, but it might be said that - as usual - they imply partly conflicting aims, like for instance 
the attempts at reconciling the condition of agriculture's competitiveness with environmental constraints. The controversy may, however, be revealed in the course of further work on the detailed solutions of the Proposal of the European Commission, even due to the different positions of the Member States. This will require compromises and even concessions, as written by, inter alia, Józwiak (2017), also at the stage of negotiating future national strategic plans.

Preparation of a strategic plan, determining specific, individualised needs for the countries justifying support from the CAP budget, indicators for achieving the objectives and selection of appropriate instruments, will be a general challenge for every European Union Member State. It is not possible to discuss all aspects of creating strategic plans in one article or to identify all challenges. Therefore, we will discuss only selected problems.

One of the main challenges for Poland is to consider, to the required extent, the objectives related to the environmental and climate policy. For the achievement of these objectives, it is planned to allocate a substantial part of the funds from the first and second pillar of the CAP. As support is increased, the intensity of obligatory environmental actions will increase, as reflected, inter alia, in the modified requirements for the beneficiaries of direct payments presently included under the "conditionality" requirements. However, increasing the financing of "environmental" actions may face barriers in Poland:

- Awareness of farmers as to the real needs of environmental and climate actions, on a scale justifying spending a significant part of the CAP budget on this purpose;

- Will of policy makers to implement objectives and measures that are more controversial, thus more difficult for implementation, settlement and control;

- Difficulties in the selection of instruments and in the determination of the amount of support;

- Measurement of effects and enforcement of actions allowing to achieve the established indicators.

In our opinion, the key challenges for shaping agricultural policy in Poland, should also include the issue of structural changes in agriculture and, more broadly, the function and place of agriculture in rural areas. These issues regularly appear in scientific publications. The broad trend of scientific discourse concerns the multifunctionality of agriculture (Wilkin, 2008), and when describing Polish agriculture, many authors emphasize its dual nature. Wigier (2013, s. 28) indicates the existence of a dominant group of farms with "low economic potential and limited development opportunities" and "commodity and economically strong" farms, which account for about $80 \%$ of food.

The same author distinguishes "small farms" and "descending" farms, which can be accepted as belonging to the category of farms with low economic potential, as well as "commodity and developing" farms and "potentially developing", which should be included in the category of "commodity and economically strong", Wigier (2013, pp. 27-28). 
From the perspective of a rural sociologist Halamska (2015) talks about farms strongly connected to the market, larger and modernizing (professional $-1 / 3$ of the total) and small, extensive and mainly producing for self-supply (quasi-peasant $2 / 3$ ). Similarly, Zietara (2009) indicates that there will be two groups of farms social and commodity - in Polish agriculture. At the same time, he emphasizes the need to distinguish farms and agricultural enterprises, appearing as two forms of economic entities in agriculture.

However, it can be concluded that these divisions do not reflect the complexity of the structure of farms in Poland. Majewski and Runowski (2015) describe contemporary Polish agriculture as "multidimensional", distinguishing hobby, self-supply, small-scale and family farms - intensive and large-scale (commercial) farms using the criterion of scale and relationships with the market. At the same time, they suggest a model of future farming defined as "co-existence" of three basic categories of farms:

- Highly productive - functioning in accordance with the paradigm of Sustainable Development, within defined intensity limits;

- "Niche" - with the dominance of production systems ensuring specific quality as understood by the consumer (organic, increased animal welfare, certified food quality, etc.) and oriented at local markets;

- Self-supplying and hobby farms.

This division develops spontaneously within the framework of functioning market mechanisms and in conditions created by the existing agricultural policy. It is obvious that modern food farms with a relatively large scale of production will decide about food supplies and competitiveness of the Polish agriculture. However, each group of farms can perform useful functions in multifunctional agriculture, also playing important roles in rural development.

The strategic plan should refer to the issue of shaping the structure of farms and the pace of structural change. Therefore, there is an urgent need to define long-term directions of agricultural development and adjust the CAP instruments accordingly in the strategic plan, taking into account both long-term transformations of agriculture and supporting the implementation of specific agricultural policy objectives for the nearest budget perspective.

The European Commission proposal also includes some detailed proposals which may be found controversial in Poland:

a. New instrument "Eco-schemes" (COM, 2018a, Article 28) enables the active implementation of climate and environmental actions financed from the first pillar of the CAP. As part of implementing the "eco-schemes", the Member States can further support, in the area eligible for direct payments, climate and environment-friendly practices going beyond the obligatory requirements under conditionality. Support under the "eco-schemes" has a form of an annual payment to each eligible hectare which compensates for the costs incurred or the lost profits as a result of the actions carried out. Despite its similar nature, support provided under the "eco-schemes" should cover actions different from those supported under the agri-climate-environmental programmes. However, 
there is a concern that in the absence of farmers willing to contract measures, the unused funds identified for the financing of eco-schemes may be lost. This indicates the risks associated with programming of this instrument. According to the authors, the implementation of the instrument is supported by the possibility of implementing relatively simple, though non-obligatory measures for the benefit of the environment and climate. The challenge is to properly program this instrument to allow for achieving the assumed goals, while not jeopardizing the achievement of the expected level of absorption of funds.

b. Another Commission proposal under "conditionality" which is obligatory balancing of biogenic elements (N, P), in Poland can also be accepted with reserve an example of which is the Government's position of August 2018: "It is necessary to rate critically, for example, making the Member States obliged to implement a complex solution, i.e. a tool related to sustainable management of nutrients, the more that this standard would apply to all farmers applying for payments" (Projekt Stanowiska RP, 2018, p. 13). This is partially understandable considering the large number of farms in Poland, probably limited capacity to perform chemical tests on a mass scale or a potential reluctance of some farmers who do not see such a need. However, the action belonging to canons of good agricultural practice, in addition relatively simple, should be implemented strictly! Tests of the soil fertility and reaction, provided that they are used to draw up fertilisation plans, should be considered one of the easiest treatments to improve the economic efficiency of plant production for the benefit of farmers and to mitigate the negative environmental impact of agricultural production, mainly on water resources. The implementation of this instrument is likely to be distributed over time, starting from larger farms and including subsequent groups of farms in subsequent years.

c. As challenges, we can also treat in Poland national arrangements regarding the agricultural support policy in a form of direct payments. The new CAP will not significantly change the system of decoupled payments ${ }^{4}$, while coupled support for income may require difficult decisions. After 2020, it will be possible for selected sectors and specific agricultural types under these sectors, provided that they are relevant for economic, social or environmental reasons (COM, 2018a, Article 30) ${ }^{5}$. According to the Commission proposal, the decisions in this regard must be justified by the results of relevant analyses. Available production support has been reduced from $15 \%$ to $12 \%$ of the first pillar (including $2 \%$ for subsidies to protein plants, not $5 \%$ as before).

\footnotetext{
${ }^{4}$ According to the authors, the success is to introduce and, above all, to maintain single area payment (SAPS system) in Poland. It is a simple solution, free from the problems arising from implementing the system of historical decoupled payments. Currently, the common return to the SAPS system is under consideration.

${ }^{5}$ Cereals, oilseeds, protein plants, legumes, flax, hemp, rice, nuts, starch potato, milk and milk products, seeds, sheep and goat meat, beef and veal, olive oil, silkworms, dried feed, hops, sugar beet, sugarcane and chicory, fruit and vegetables, short-rotation coppices and other non-food crops, excluding trees, used for the manufacture of products which may replace fossil materials (COM, 2018a, Article 30).
} 
In the current financial perspective, coupled support is granted to a wide range of activities and access to these instruments is not dependent on meeting additional requirements. Therefore, decision-makers face difficult challenges, particularly when we take into account the power of various agricultural lobbies (Poczta-Wajda, 2017), how to distribute available funds for decoupled payments so as to achieve the possible CAP objectives in the best possible manner and to allocate resources effectively. For example, it is possible to doubt whether to support the production of dairy cattle in areas with the high growth rate of milk production, where the increased intensity of production can pose a threat to the environment. For the same reason, we may consider to limit support for the animal production on high stocking density farms. Similar dilemmas may apply to each supported production activities, as well as the involvement, so far, of considerable funds in co-financing with these payments of small farms, with a negligible share in the market of agricultural and food products.

Looking from this perspective, we may be wondering about the validity of support for the so-called small processing on farms, development of micro-enterprises on rural areas as well as reimbursement of costs for participation of farmers in quality schemes. Unfortunately, these instruments have not been included in the proposed regulation. If such support would not be included in the new CAP, it still deserves maintaining national financing if it is possible to agree this with the European Commission.

d. As one of the challenges, we can consider the adoption of the principle of solving the problem of unequal distribution of direct payments, however, it seems that in Poland this is not a priority issue. According to the proposal of the European Commission, the reduction in the highest amounts of direct payments applies to a relatively small number of farms receiving more than the threshold of EUR 60,000 laid down in the regulation. In Poland, such farms receive around 6\% of the direct payments envelope, while in the European Union this is the amount of $16 \%$ of the funds (especially in the countries such as the Czech Republic, Slovakia, Germany, Denmark, etc.), (Projekt Stanowiska RP, 2018).

The proposal of the European Commission assumed the minimum rates of reduction of the amounts to be paid. According to the proposal, the amounts of subsidies minus the estimated costs of unpaid and paid labour will be reduced by at least $25 \%$ within the range of EUR $60-75$ thousand, $50 \%$ within the range of EUR 75-90 thousand, 75\% within the range of EUR 90-100 thousand. No excess payments exceeding, after deduction of labour costs, EUR 100 thousand will be paid.

The use of the mechanism as proposed in the regulation does not significantly affect the average level of direct payments country-wide. The reduction in payments relates to a small number of Polish farms, but in some voivodeships, e.g. Zachodniopomorskie and Opolskie, the share of payments paid to farms in the amount of more than EUR 60,000 (without deduction of labour costs) exceeds $20 \%$ of the amount of direct payments in those voivodeships. This instrument is particularly severe for the largest farms. The possibility of avoiding reductions 
by increasing labour costs, which is an inherent part of the payment reduction mechanism, can foster increased employment on the largest farms, assuming that labour resources are available and that there are at least partially justified needs for additional employment.

In analysing this instrument, it should be noted that the funds "saved" through decreased payments can be transferred to the actions financed from the second pillar of the CAP. Due to the diversified farm structure, this would also mean the transfer of funds among the regions (the largest percentage of reductions would occur in the Opolskie and Zachodniopomorskie voivodeships, where there is the largest percentage of farms subject to a possible reduction in subsidies).

The scale of transfers of funds resulting from the payment reduction mechanism remains largely the responsibility of the Member States. The transfer of amounts from the first to the second pillar may be increased by applying the rates which are higher than the proposed reduction rates, as well as minimised by adopting the relatively high rates when estimating the costs of unpaid and paid labour for the purposes of determining the amounts to be reduced. Preliminary estimates indicate that, in the case of applying the lowest payment reduction rates and resigning from the possible deduction of labour costs from subsidies, the amount obtained due to reduction of the direct payments would be even PLN 500 million a year. However, having considered the costs of unpaid and paid labour estimated on the basis of average remuneration in the economy published by the GUS (2017), the payment reduction for large farms is so negligible that this instrument almost loses its significance. The method of estimating labour costs and the decision on increasing the payment reduction rates remain the responsibility of the Member States. Before deciding on this issue, it is necessary to determine whether any potential "savings" made at the expense of the largest farms could be spent in a more efficient way.

Although it seems that the economic effects of this instrument will not be major, for reasons of image it would be reasonable to consider its application. Limiting payments, in line with the principles noted in the Commission's proposal, in addition to a more even distribution of aid funds, could encourage employers to increase employment, as labour costs are deducted from the payment amount covered by the reduction. This may be conducive to reducing unemployment in rural areas, provided that there is a surplus of labour resources. Otherwise, this type of incentive will not be effective.

e. Improving the competitiveness of agriculture and empowering farmers in the supply chain are two specific objectives of the new CAP, which are important for the Polish agriculture in particular in the context of the existing fragmentation of the agrarian structure of farms in Poland. This entails further challenges for shaping the agricultural policy in relation to Polish agriculture and rural areas.

The dynamics of the concentration processes in agriculture is significantly lower than the rate of consolidation of processing and commercial operators. This results in a systematic reduction in the bargaining power of farmers, thereby facilitating the drainage of the agricultural surplus from the sector of farms to another links in 
the supply chain. Thus, the question arises about the effective ways of intervention in this area. It can be assumed that the acceleration of the concentration processes in the agricultural sector, including horizontal integration, by creating new and strengthening existing producer groups, would serve this purpose, although would not be sufficient. With the simultaneous support for farmers' income, this would in the extreme case lead to a situation, where some funds allocated for supporting farmers' income would go indirectly to processing enterprises and trade which, using their advantage, will be able to force farmers to reduce buying-in prices of raw materials, or deliver means of production at inflated prices.

Finding solutions that do not interfere with market mechanisms seems to be particularly difficult in this case. In addition to deepening the concentration of production factors and increasing the scale of production in the agricultural sector, a more important role could be played by: better cooperation manifested in various forms of self-organization of producers (horizontal integration) and increased degree of coopetition - partnership cooperation between links in integrated supply chains.

\section{Summary}

The new model of the CAP after 2020 has not yet been approved by the European Parliament. However, it is very likely that the proposal of the European Commission will not be radically changed. As the basic characteristics of the new model of the CAP, compared to the existing rules, we can consider the fact that the individual Member States have a lot of freedom in shaping their national agricultural and rural policies, but are responsible for determining measurable effects and for selection of instruments, while retaining the community character of the CAP. The individualisation of the shape of the CAP in the Member States can be considered as one of the most significant achievements in the proposal of the European Commission. The existing, universal CAP mechanisms, although quite effectively reconciling the conflicting objectives of the agricultural policy and sometimes contradicting interests of the EU countries, became increasingly troublesome to maintain.

As to the essence of the Common Agricultural Policy of the EU, it seems that there have been no radical changes. The main objectives of the CAP are still to support agricultural income, to enhance the competitiveness of the EU agriculture, or to support rural development. On the other hand, the most important changes that emerge from the proposal of the European Commission should primarily include:

- New model of shaping and enforcing the CAP objectives through individualisation (adaptation to specific conditions) of national policies and transfer of responsibilities for developing strategic plans and their implementation to Member States;

- Stronger emphasis on environmental objectives and linking the CAP with the climate policy;

- Modification of existing and adding new, specific CAP objectives;

- Possibility of transferring funds between the pillars of the CAP. 
The effects of implementing the new CAP model will be largely dependent on Member States' decisions on the shape of strategic plans, including the selection of objectives and instruments, as well as on the involvement of farmers and other stakeholders in the implementation of the adopted plans. At the same time, the new CAP is expected to contribute to meeting international commitments on the environmental impact of agriculture, such as 2030 Agenda for UN Sustainable Development Agenda, the Paris Agreement on climate change and the Convention on Biological Diversity as well as obligations under the concluded treaties and trade agreements. The EU food sector benefits from international trade but will also be subjected to a greater competitive pressure, potentially severe in particular for vulnerable branches of agricultural production (IEEP, 2018).

The effectiveness of the new CAP in the incoming budgetary perspective may be likely affected by the turbulent phenomena whose implications are difficult to be predicted. The United Kingdom's exit from the European Community is already foregone, with the immediate effect of depletion of the CAP budget. In the longer term, there is a risk of a slowdown in the global economy, a decline in the global food demand despite the growing population and the production risk in agriculture is increasing due to the increased occurrence of adverse weather events.

Finally, the implementation of the new CAP model is linked to changes in the relations between the European Commission and the Member States. The proposal of the European Commission stresses the simplification of the CAP, but it seems that this is a proposal formulated mainly from the perspective of the European Commission. The main burden of work on the shape of individualised national member policies is, in fact, on the Member States, while the European Commission will approve national solutions and monitor the level of achieving the established indicators.

For Poland, just like for all Member States, a key challenge is a difficult task to objectively identify the needs of the agriculture and rural sector and then to select indicators and instruments enabling the effective achievement of the CAP objectives.

One of the main challenges for Poland seems to be to include in the strategic plans the objectives of the environmental and climate policy. The tools that can arouse discussion as to the legitimacy and form of implementation are, inter alia, "eco-schemes" or obligatory balancing of biogenic elements. Their implementation is supported by a possibility of implementing relatively simple environmental and climate actions, financed by the first pillar of the CAP. Tests of the soil fertility and reaction, provided that they are used to draw up fertilisation plans, should be considered one of the easiest treatments to improve the economic efficiency of plant production and to mitigate the negative environmental impact of agricultural production, mainly on water resources.

Another major challenge for Poland in the new CAP are the national arrangements for the agriculture support policy in a form of direct payments and the principle of tackling the problem of inequalities in their distribution. There are difficult challenges for decision-makers on how to allocate available funds for decoupled 
payments so as to achieve the CAP objectives in the best possible manner and to effectively allocate the funds and to what extent transfer the funds between the first and the second pillar of the CAP.

The main objective of this study was to identify the major implications and challenges resulting from the new model for the functioning of the CAP in the EU after 2020. Due to its complexity, the article does not exhaust the fully-described topic, outlining only some of the most important issues. However, we hope that it will inspire to start a national discussion on the shape and detailed solutions for the new CAP in Poland. 


\section{References}

Agenda 2000 (1997). For a Stronger and Wider Union. Vol. I - Communication, DOC/97/6, Strasbourg, 15 July 1997.

COM (2017). Communication from the Commission to the European Parliament, the Council, the European Economic and Social Committee and the Committee of the Regions. The Future of Food and Farming. COM(2017) 713. Brussels: Publications Office of the European Union.

COM (2018a). Rozporządzenie Parlamentu Europejskiego i Rady UE, COM(2018) 392 - wniosek - ustanawiające przepisy dotyczące wsparcia na podstawie planów strategicznych sporządzanych przez państwa członkowskie w ramach wspólnej polityki rolnej (planów strategicznych WPR) i finansowanych z Europejskiego Funduszu Rolniczego Gwarancji (EFRG) i z Europejskiego Funduszu Rolnego na rzecz Rozwoju Obszarów Wiejskich (EFRROW) oraz uchylające rozporządzenie Parlamentu Europejskiego i Rady (UE) no. 1305/2013 i rozporządzenie Parlamentu Europejskiego i Rady (UE) no. 1307/2013 - dokument COM(2018) 392 final z dnia 1.6.2018.

COM (2018b). Towards a Performance. Monitoring and Evaluation. Framework for the CAP post-2020. DG Agriculture and Rural Development. European Commission.

COM (2018c). EU Budget: the Common Agricultural Policy after 2020 (2018). Retrieved from: https:/ec.europa.eu/commission/news/eu-budget-common-agricultural-policy-after-20202018-jun-01_en.

EEB (2018). Open Letter to EU Ministers of Agriculture; European Environmental Bureau. Retrieved from: http://www.birdlife.org/sites/default/files/attachments/letter_-19_february_agriculture_council.pdf.

GUS (2017). Komunikat Prezesa Głównego Urzędu Statystycznego z dnia 9 lutego 2018 r. w sprawie przeciętnego wynagrodzenia w gospodarce narodowej w 2017 r. Warszawa: GUS.

Halamska, M. (2015). Specyfika rolnictwa rodzinnego w Polsce: ciężar przeszłości i obecne uwarunkowania. Wieś i Rolnictwo, No. 1(166), pp. 107-129.

Haniotis, T. (2018). The proposed shift of the CAP from compliance to performance: chalenges, impacts and opportunities for a knowledge-based EU agriculture (DG-AGRI). Prezentacja z seminarium "CAP post 2020 Debate", Madryt 10.05.2018.

Hart,K., Mottershead,D., Tucker,G.,Underwood,E., Maréchal,A., Menet,L., Martin, I., Dayde, C., Bresson, C., Deniel, E., Sanders, J., Röder, N., Osterburg, B., Klages, S., Schwaiger, E., Schwarzl, B., Färber, B., Pražan, J., Daydé, C., Zemeckis, R., Kuneman, G., van Dijk, W., de Lijster, E., Łopaciuk, W., Redman, M., Barbu, R., Oñate, J., Radley, G., Turpie, S. (2017). Evaluation study of the payment for agricultural practices beneficial for the climate and the environment. Final Report, Alliance Environnement and the Thünen Institute; Brussels.

Hogan, P. (2018). Common Agricultural Policy post-2020 simplification and modernization. Retrieved from: https://ec.europa.eu/info/sites/info/files/food-farming-fisheries/key_policies/presentations/simplification_moder nisation_cap.pdf.

IEEP (2018). Mottershead, D., Hart, K., Maréchal, A., Meed.th, S., Lorant, A., Bas-Defossez, F., Baldock, D., IEEP, J.-C. Bureau, Matthews, A. (2018). Research for AGRI Committee Towards the CAP post 2020 - Appraisal of the EC Communication on 'The Future of Food and Farming' of 29 November 2017. European Parliament, Policy Department for Structural and Cohesion Policies, Brussels.

Józwiak, W. (2017). Wspólna Polityka Rolna po 2020 roku - kontynuacja obecnej praktyki czy zerwanie z nią. Zagadnienia Ekonomiki Rolnej, No. 3(352) 2017, pp. 3-18.

KOBiZE (2018). Greenhouse Gas Inventory for 1988-2016. Poland's National Inventory Report 2018. Warszawa. 
Król, M.A. (2013). Ekologizacja Wspólnej Polityki Rolnej - zagadnienia prawne. Zeszyty Naukowe SGGW. Polityki Europejskie, Finanse i Marketing, No. 10(59), pp. 402-421.

Majewski, E., Malak-Rawlikowska, A. (2018). Scenariusze wspólnej polityki rolnej po roku 2020. Zagadnienia Ekonomiki Rolnej, No. 1(354), pp. 9-38.

Majewski, E., Runowski, H. (2015). Ekonomiczno-organizacyjne uwarunkowania rozwoju rolnictwa w Polsce. In: E. Chyłek (ed.), Badania naukowe w procesie kształtowania polskiej wizji wspólnej polityki rolnej i wspólnej polityki rybackiej. III Kongres Nauk Rolniczych „Nauka - Praktyce” (pp. 207-221). Warszawa: MRiRW.

Matthwes, A. (2017). Decoding the CAP Communication. Retrieved from: http://capreform.eu/ decoding-the-cap-communication/, CAP Reform.eu.

Pe'er, G., Lakner, S., Müller, R., Passoni, G., Bontzorlos, V., Clough, D., Moreira, F., Azam, C., Berger, J., Bezák, P., Hansjürgens, B., Hartmann, L., Kleemann, J., Lomba, A., Sahrbacher, A., Schindler, S., Schleyer, C., Schmidt, J., Schüler, S., Sirami, C., von Meyer-Höfer, M., Zinngrebe, Y., Bonn, A. (2017). Is the CAP Fit for purpose? An evidence-based fitness-check assessment. Report, iDiv Leipzig, Birdlife Brussels and NABU Berlin.

Poczta-Wajda A., (2017), Polityka wspierania rolnictwa a problem deprywacji dochodowej rolników w krajach o różnym poziomie rozwoju. PWN Warszawa 2017.

Projekt stanowiska RP (2018). Projekt stanowiska 29.08.2018 roku w związku z art. 7 ustawy z dnia 8 października 2010 r. o współpracy Rady Ministrów z Sejmem i Senatem w sprawach związanych z członkostwem Rzeczypospolitej Polskiej w Unii Europejskiej (Dz.U. nr 213, poz. 1395) w odniesieniu do dokumentów KE COM (2018)392, COM (2018)393, COM (2018)394. Retrieved from: https://www.gov.pl/documents/912055/913531/Za\%C5\%826_ Stanowisko_RP_dot_pakietu_WPR_po_2020_roku_-_COM\%282018\%29_392_393_394. pdf/cd795bba-aabf-6b2a-2c9e-f6d8dc51826c.

Sulewski, P., Majewski, E., Wąs, A. (2018). Supporting Sustainable Agriculture: the Potential to Reduce GHG Emissions - the Case of Agricultural Biogas Production in Poland. Rocznik Ochrona Środowiska, vol. 20.

Wigier, M. (2013). Model rozwoju rolnictwa polskiego w świetle efektów realizacji WPR. Zagadnienia Ekonomiki Rolnej, No. 1(334), pp. 22-41.

Wilkin, J. (2008). Wielofunkcyjność rolnictwa i obszarów wiejskich. In: M. Kłodziński (ed.), Wyzwania przed obszarami wiejskimi i rolnictwem w perspektywie lat 2014-2020 (pp. 9-20). IRWiR, Warszawa.

Ziętara, W. (2009). Model polskiego rolnictwa - wobec aktualnych wyzwań. Zeszyty Naukowe SGGW. Ekonomika i Organizacja Gospodarki Żywnościowej, No. 73, pp. 5-21. 


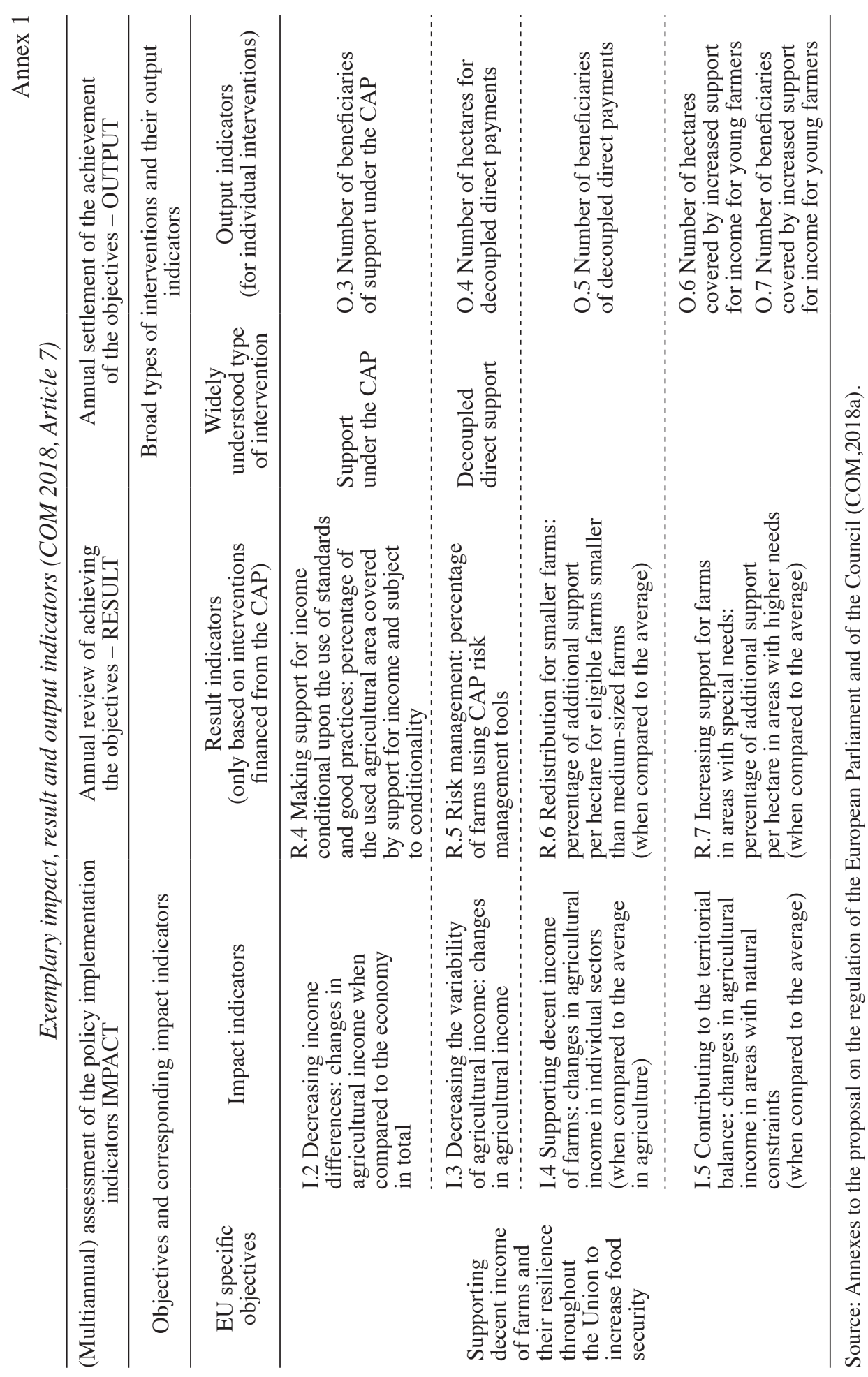




\title{
NOWY MODEL FUNKCJONOWANIA WSPÓLNEJ POLITYKI ROLNEJ UE PO ROKU 2020 - WYZWANIA DLA POLSKI
}

\begin{abstract}
Abstrakt
Wspólna polityka rolna (WPR) Unii Europejskiej będzie przedmiotem kolejnej reformy, której założenia przedstawiono w propozycji Komisji Europejskiej z 1 czerwca 2018 roku. Określono $w$ niej proponowane formy i zakres wsparcia unijnego rolnictwa po 2020 roku. Nowatorskie rozwiazania, jakie sugeruje Komisja Europejska, nakładaja wiele nowych obowiazków na państwa członkowskie. Niosa jednak ze soba istotne wyzwania wynikajace zarówno z konieczności zdefiniowania krajowych strategii, jak i potrzeby wdrożenia rozwiąań instrumentów politycznych i mierzenia efektów realizacji polityki.

Głównym celem niniejszego opracowania jest rozważenie kluczowych zdaniem autorów implikacji dla Polski wynikajacych z proponowanego po 2020 roku nowego modelu funkcjonowania WPR oraz wskazanie najważniejszych wyzwań dla decydentów politycznych i catego sektora rolnictwa.

W nowej WPR nie nastapity, jak się wydaje, radykalne zmiany co do samej istoty wspólnej polityki rolnej UE. Do zasadniczych celów WPR ciagle należy wspomaganie dochodów rolniczych, poprawa konkurencyjności unijnego rolnictwa, czy też wspieranie rozwoju obszarów wiejskich. Za podstawowy wyróżnik nowego modelu WPR, w porównaniu z dotychczas obowiazujacymi regułami, można uznać duży zakres swobody poszczególnych państw członkowskich $w$ kształtowaniu krajowej polityki w odniesieniu do rolnictwa i obszarów wiejskich z zachowaniem wspólnotowego charakteru WPR, ale również obowiazek określenia mierzalnych efektów i doboru instrumentów.

Dla Polski, podobnie zreszta jak dla wszystkich państw członkowskich, kluczowym wyzwaniem staje sie niełatwe zadanie obiektywnej identyfikacji potrzeb sektora rolnictwa i obszarów wiejskich, a nastepnie dobór wskaźników i instrumentów umożliwiajacych skuteczne osiaganie celów WPR. Jednym z podstawowych wyzwań dla Polski jest też uwzględnienie $w$ planach strategicznych celów zwiazanych z polityka środowiskowa i klimatyczna oraz poprawa pozycji rolników w łańcuchu żywnościowym. Kolejna kwestią, która budzi dyskusje, jest określenie polityki wsparcia rolnictwa $w$ formie płatności bezpośrednich oraz zasady rozwiązania problemu nierówności w ich dystrybucji.
\end{abstract}

Słowa kluczowe: wspólna polityka rolna, rolnictwo, wspieranie rolnictwa, polityka rolna UE, reformy WPR.

Accepted for print: 18.12.2018.

Unless stated otherwise all the materials on the website are available under the Creative Commons Attribution 4.0 International license.

Some rights reserved to the Institute of Agricultural and Food Economics - National Research Institute.

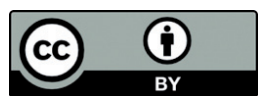

